\title{
Televisi Publik: Kajian tentang Opini Masyarakat Kota Bandung mengenai TV Publik
}

\author{
Betty RF Sabur
}

\begin{abstract}
This research was aimed to analyze several aspects of Public TV in its preparation phase. The focus is directed toward socialization, cognition, judgment, aspirations, and contributions of Public TV to the people of Bandung City. By employing analytical descriptive as methods to addressing research questions, about 250 respondents were asked to fill questionnaires. In-depth interviews to prominent members of society, media experts, and others related with such problems were also carried out. The research has led to some findings, e.g. cognition and judgment levels socialization is on average. The most important thing for the public, considering the importance of Public TV, is the dominant functions of Public TV to represent education and cultural programs. If managed by idealism toward education and leveraging people's quality, Public TV would create a positive image for itself.
\end{abstract}

Kata kunci: TV publik, opini, media massa

\section{Pendahuluan}

\subsection{Latar Belakang Penelitian}

Penerapan ide radio televisi publik dalam konteks di tanah air, tentu berhadapan dengan sejumlah masalah di luar kemungkinan adanya penolakan dari pihak lembaga penyiaran itu sendiri. Artinya, penerapan ide tersebut dapat menghadapi berbagai masalah. Menurut Dedy N. Hidayat (2001), beberapa di antara masalah tersebut meliputi:

Pertama, perbedaan sumber daya atau kemampuan antarkelompok publik untuk mempresentasikan ide, sikap, serta aspirasi mereka dalam program siaran. Hal ini tentu menuntut adanya upaya-upaya berbagai pihak untuk berperan serta memberdayakan kelompok- kelompok publik dalam memanfaatkan akses ke media penyiaran melalui pelatihan keterampilan yang diperlukan.

Kedua, masalah toleransi publik sendiri terhadap pendapat dan pandangan yang berbeda, ekspresi gaya hidup, serta budaya alternatif atau eksperimental.

Ketiga, masalah yang berkaitan dengan kemungkinan dimanfaatkannya akses publik tersebut oleh kelompok-kelompok politik yang terlibat konflik horisontal ataupun dimanfaatkan oleh kelompok sosial tertentu untuk tujuan-tujuan yang bisa merugikan kelompok lain.

Oleh karena itu, akses publik perlu lebih diprioritaskan kepada organisasi non-politik, lembaga-lembaga swadaya masyarakat, kelompokkelompok advokasi nirlaba, yang membawakan isu- 
isu kepentingan publik secara umum yang bersifat lintas partai dan ideologi politik atau pun lintas pengelompokkan etnis dan agama.

Dapat dipahami bahwa wajar apabila publik menggantungkan harapannya pada TV publik yang mengutamakan program-program yang berorientasi pada kepentingan publiknya. Oleh karena itu, sebagai lembaga penyiaran publik, maka TVRI/RRI perlu melakukan usahanya untuk memperbesar peran keberadaan stakehoolder-nya. Misalnya, proses dan bentuk keterlibatan langsung publik dalam menyusun pola siaran dari program acara yang akan disajiikan. Tidaklah mungkin suatu penyiaran publik dapat menyerap dengan baik aspirasi publik, apabila masih banyak hal yang segala sesuatunya lebih ditentukan oleh para pengelola siaran saja. Selain itu, transparansi profesionalisme serta akuntabilitas pengelolaan institusi juga harus diperhatikan. Hal-hal inilah yang perlu diperhatikan agar dukungan publik semakin meluas.

Keterlibatan publik seperti dikemukakan di atas, akan membuka cakrawala baru bagi masyarakat yang membutuhkan alternatif penyiaran lain. Banyak anggota masyarakat yang merasakan tidak punya pilihan program siaran televisi yang lebih sehat akibat gencarnya beberapa jenis program dari televisi-televisi swasta.

Sementara itu, M. Abduh Aziz (2001), mengemukakan bahwa pilihan wacana publik yang relevan, tidak bisa bicara lain harus berangkat dari apa yang disepakati sebagai kepentingan publik. Pilihannya memang sangat sulit ketika muncul pertanyaan apa yang dimaksud dengan kepentingan publik. Tetapi, mungkin tidak terlalu sulit kalau mengaitkannya dengan kondisi faktual bangsa ini dan persoalan-persoalan mendasar yang tengah dihadapinya, misalnya pendidikan, kemiskinan dan keadilan, pemerintahan yang bersih, korupsi ataupun persoalan multikultur yang dapat melibatkan konflik horisontal seperti agama, suku, ras, dan antargolongan (SARA).

Kita mengetahui jasa penyiaran publik adalah sistem penyiaran yang nirlaba yang ditunjang oleh dana publik, dan tanggung jawabnya, terutama, ditujukan kepada masyarakat, menyediakan jasa bagi publiknya, serta tidak menggunakan prinsipprinsip komersialitas sebagai alat uuntuk menentukan penyusunan program penyiarannya. Pasal 12 ayat 1 UU Penyiaran mendefinisikan konsep ini dengan menyatakan: "Lembaga penyiaran publik adalah lembaga penyiaran berbentuk badan hukum yang didirikan negara, independen, bersifat tidak komersial dan berfungsi memberikan pelayanan untuk kepentingan masyarakat."

Berkaitan dengan TV Publik ini, permasalahan yang belum disentuh adalah bagaimana opini masyarakat tentang TV Publik? Apakah kehadiran TV Publik itu hanya keinginan suatu kelompok masyarakat saja, atau memang masyarakat yang secara luas memerlukan kehadiran TV Publik, di mana pemirsanya banyak diterpa TV komersial?

Oleh karena itu menjadi permasalahan adalah "bagaimana opini masyarakat tentang TV Publik baik dari masyarakat luas maupun kalangan praktisi dan teoretisi bidang televisi ataupun lembaga yang berkaitan dengan penyiaran. Perlu dikemukakan bahwa penelitian ini dibuat sebagai awal dari atau saat TV Publik belum direalisasikan. Sebab, dianggap perlu dilakukan kajian awal sehingga setelah TV Publik direalisasikan, kemudian dapat dibuat lagi penelitian lanjutannya.

\subsection{Perumusan dan Identifikasi Masalah}

Perumusan masalah yang akan dikaji ini adalah "Bagaimana opini masyarakat terhadap TV Publik"

Dari rumusan tersebut, beberapa hal dapat diidentifikasikan sebagai beriikut:

(1) Bagaimana karakteristik sosio demografis masyarakat?

(2) Bagaimana sosialisasi TV Publik pada masyarakat?

(3) Bagaimana kognisi (pengetahuan) masyarakat tentang TV Publik?

(4) Bagaimana penilaian masyarakat tentang TV Publik?

(5) Apa harapan masyarakat tentang kehadiran TV Publik?

(6) Bagaimana kontribusi masyarakat pada TV Publik? 


\subsection{Tujuan Penelitian}

Adapun tujuan penelitian ini ialah untuk mengetahui:

(1) Karakteristik sosio demografis masyarakat/ publik

(2) Sosialisasi TV Publik pada masyarakat

(3) Kognisi (pengetahuan) masyarakat tentang TV Publik

(4) Penilaian masyarakat tentang TV Publik

(5) Harapan masyarakat tentang kehadiran TV Publik

(6) Bagaimana kontribusi masyarakat pada TV Publik

\subsection{Kontribusi Kajian}

1) Secara praktis, penelitian ini diharapkan dapat memperkaya data empiris pola interaksi dan komunikasi yang lebih harmonis, di tengah berbagai konflik sosial yang melanda negeri ini. Secara khusus melalui penelitian ini diharapkan ada kontribusi tentang pandangan masyarakat pada TV Publik.

2) Secara teoritik penelitian ini diharapkan akan dapat merupakan landasan bagi penelitian setelah direalisasikannya TV Publik.

\subsection{Metodologi Penelitian}

Rancangan atau metode dalam kajian ini yang berupa penelitian bersifat deskriptif, dengan pendekatan survei. Populasi penelitian ini adalah masyarakat Kota Bandung.

Teknik sampling yang digunakan adalah multi stage area sampling. Dari teknik ini diiperoleh 250 (dua ratus lima puluh) Kepala Keluarga/Umpi.

Teknik pengumpulan data penelitian ini melalui angket dan studi pustaka. Juga dilakukan wawancara mendalam dengan tokoh-tokoh praktisi dan teoritisi bidang televisi atau yang berkaitan dengan media.

\section{Tinjauan Pustaka}

\subsection{Karakteristik Sosio Demografis}

Berbicara tentang karakteristik sosio demografis dapat mengacu kepada pendapat De
Fleur dan Ball Rokeach (1993), yang mengemukakan bahwa pendapat tiga perspektif untuk melihat perbedaan khalayak dalam memilih media, yaitu perspektif perbedaan individu, perspektif kategori sosial dan perspektif hubungan sosial.

Perspektif perbedaan individu melihat bahwa sikap kondisi personal psikologis individu menentukan bagaimana individu tersebut memilih stimuli dari lingkungan, dan bagaimana ia memberi makna pada stimuli tersebut. Setiap orang memiliiki potensi biologis, pengalaman belajar dan lingkungan yang berbeda. Perbedaan ini mempengaruhi mereka memilih media, sekaligus juga berpengaruh kepada media yang berbeda.

Perspektif kategori sosial menilai bahwa dalam masyarakat terdapat kelompok-kelompok sosial, yang reaksinya cenderung sama. Golongan sosial berdasarkan karakteristik demografis, seperti usia, jenis kelamin, tingkat ekonomi, tingkat pendidikan, dapat menampilkan kategori respons. Anggota kategori tertentu cenderung akan memilih isi pesan yang sama dan akan memberi respons yang sama pula.

Perspektif hubungan sosial menekankan pentingnya peranan hubungan sosial yang informal dalam mempengaruhi reaksi terhadap media. De Fleur menunjukkan dengan suatu model komunikasi dua arah (two step flow of communication), di mana informasi bergerak dua tahap. Pertama, informasi menerpa sekelompok individu yang relatif lebih tahu dan lebih terterpa oleh media massa. Kedua, informasi bergerak dari sekelompok orang tersebut, yang biasanya disebut sebagai pemuka pendapat, melaluui saluran interpersonal disampaikan pada individu bergantung pada mereka.

De Fleur menjelaskan faktor-faktor yang mempengaruhi reaksi orang terhadap media, termasuk pemilihan media, meliputi faktor organisasi personal-psikologis individu, seperti potensi biologis, sikap, nilai, kepercayaan, serta bidang pengalaman kelompok sosial di mana individu menjadi anggota, hubungan-hubungan interpersonal dalam proses penerimaan, pengolahan dan penyampaian informasi. Diketahui bahwa orang yang berpendidikan rendah jarang 
membaca suratkabar, tetapi sering menonton televisi. Eksekutif dan kaum bisnis menyenangi rubrik niaga dalam surat kabar atau majalah. Berdasarkan penelitian diketahui bahwa kelompok menengah tersebut cenderung menyukai kolomkolom / program-program / rubrik tentang pendidikan, berita dan informasi.

\subsection{Opini (Pendapat)}

Azwar (1995 : 9) menyatakan bahwa opinion (opini) merupakan pernyataan sikap yang sangat spesifik atau sikap dalam artian yang sempit. Opini terbentuk didasari oleh sikap yang sudah mapan, opini lebih bersifat situasional dan temporer. Opini juga mudah berubah sesuai dengan kondisinya.

Opini merupakan penilaian tentang objek yang diekspresikan dalam situasi tertentu. Opini cenderung mencerminkan sikap yang berhubungan dari individu, tetapi memperhitungkan aspek situasi yang sedang berlangsung dan dipandang lebih kognitif(Cutlip, 2005 : 215).

Selain itu opini dapat dikatakan lebih merupakan pernyataan dan pengucapan kata-kata atau cara-cara lain yang mengandung arti. Suatu opini harus dinyatakan supaya dapat dinilai atau ditanggapi publik.

\subsection{Sosialisasi}

Sosialisasi antara lain dapat diartikan sebagai pengenalan, pemasaran sosial (kampanye sosialkemasyarakatan) atau iklan dan promosi (dalam dunia bisnis) publisitas (dalam dunia Public Relations), dengan tujuan agar khalayak atau masyarakat yang menjadi target publik sosialisasi menjadi tahu, sadar, bahkan memiliki sikap dan akhirnya melakukan tindakan seperti pesan yang disampaikan dalam sosialisasi tersebut.

Sosialisasi juga bisa berarti label yang diberikan untuk sesuatu yang komplek dalam jangka panjang dan multi dimensional terhadap perubahan komunikasi antara seseorang dengan pelbagai agen dari masyarakat yang tujuannya untuk menyiapkan pribadi agar bisa hidup dalam suatu lingkungan sosial budaya. Dari perspektif individu maka sosialisasi membantu untuk berkomunikasi, berfikir, memecahkan masalah dengan teknik yang pas bagi masyarakat dan secara umum dapat membuat kita beradaptasi secara unik dengan lingkungan pribadi kita. Dengan memahami pandangan tentang masyarakat maka sosialisasi dapat membawa anggotanya ke dalam suatu proses penyesuaian dengan aturan sosial yang ada maupun aturan yang akan diramal dan datang kemudian (Liliweri, 1991).

Media massa berperan dalam sosialisasi pesan-pesan untuk mendorong dan membangkitkan unsur Id (istilah dari Freud tentang hasrat hewani) yang dimiliki oleh pembaca maupun pemirsanya. Media massa dalam banyak hal dapat membangkitkan selera rendah, selera hewani secara berlebihan dari manusia, misalnya mendorong nafsu makan, mengkonsumsi makanan dan pakaian, membangkitkan gairah seksual.

Selain dapat membangkitkan Id, media juga dapat mempengaruhi kesadaran manusia melalui penerimaan melalui unsur ego. Orang belajar mengetahui sesuatu demi peningkatan pengetahuannya, pandangan, dan pendapatnya serta keyakinannya secara intelektual. Media melalui pesan-pesannya membangkitkan gairah ingin tahu.

Media massa melalui pesannya dapat mempengaruhi bangkitnya unsur superego; dengan unsur ini seseorang yang diterpa media diharapkan dapat mengendalikan dirinya, mengatur dirinya, menata kembali nilai dan normanya.

Sosialisasi juga dapat dikatakan sebagai upaya untuk melanjutkan sistemnya menjadi lebih stabil. Perjuangan itu terjadi secara konstan dari anggotanya semenjak lahir sampai kematiannya demi kelangsungan sistem secara kontinyu. Hal ini mungkin terjadi karena dasar dari organisasi sosial dan kebudayaan secara umum ditransmisikan melalui proses sosial. Dalam hal ini media bisa membantu proses tersebut.

Jadi, kita dapat dikatakan bahwa media berperan dalam proses sosialisasi karena bisa mempengaruhi pelbagai pesan yang menerpa individu dan hubungan antara pribadi dengan kelompok sosialnya. Media sangat kuat perannya untuk menggambarkan hal-hal yang ada tentang hubungan antara individu dengan kelompoknya, 
Terakreditasi Dirjen Dikti SK No. 56/DIKTI/Kep/2005

maupun masyarakat pada umumnya. Umumnya proses sosialisasi diarahkan untuk mempengaruhi unsur dasar suatu budaya seperti gaya hidup tradisional, bahasa, aturan-aturan untuk kehidupan moral dan hal-hal lainnya.

Dipandang dari aspek lain efek sosialisasi pesan media bagi setiap orang tidaklah sama, mungkin perbedaan itu didasarkan pada segmen khalayak apakah itu demografis atau aspek lain yang dimiliki khalayak. Dengan demikian sebenarnya ada perbedaan efek pesan itu pada seseorang mungkin karena tingkat pendidikan, usia, pendapatan, norma dan nilai yang mewarnai gaya hidup seseorang. Dalam hal ini teori Kategori Sosial dapat memberikan penjelasan lebih jauh.

\subsection{Efek Media Televisi}

Efek media massa televisi, tentunya dapat dilihat dengan adanya sejumlah penelitian khalayak, yaitu upaya mencari data tentang khalayak (sebagian pengguna media massa). Data yang dicari melalui riset khalayak dapat dikelompokkan ke dalam audience profile (profil khalayak), media exposure (terpaan media), audience rating (peringkat khalayak) dan efek komunikasi bermedia.

Profil khalayak sendiri dapat mencakup variabel-variabel: jenis kelamin, umur, tingkat pendidikan, pendapatan, kedudukan/jabatan, pemilikan media. Dari data tersebut dapat diketahui gambaran khalayak suatu media massa atau suatu acara tertentu. Dari berbagai variabel dalam profil khalayak ini dapat dikorelasikan dengan variabelvariabel lainnya sesuai dengan kepentingan riset sehingga tujuan riset dapat dicapai.

Terpaan media berusaha mencari data khalayak tentang penggunaan media baik jenis media, frekuensi penggunaan maupun durasi penggunaan. Penggunaan jenis media meliputi media audio, audio visual, media cetak, kombinasi media audio dan media audio visual, media audio dan media cetak, media audio visual dan media cetak serta media audio, audio visual dan media cetak. Frekuensi penggunaan media mengumpulkan data khalayak tentang berapa kali sehari seseorang menggunakan media dalam satu minggu (untuk meneliti program harian); berapa kali seminggu seseorang menggunakan media dalam satu bulan (untuk program mingguan dan tengah bulanan), serta berapa kali sebulan seorang menggunakan media dalam satu tahun (untuk program bulanan).

Audience rating digunakan untuk mengetahui perhatian khalayak terhadap jenis media, jenis informasi, format acara dan komunikator yang menjadi favorit khalayak. Peringkat khalayak sangat baik dilakukan untuk mencari informasi yang paling dibutuhkan khalayak, media yang sering digunakan khalayak, format acara yang paling disenangi khalayak, dan komunikator (broadcaster, newscaster, reporter dan lainnya) yang paling disukai khalayaknya dalam menyampaikan pesan-pesan.

Penelitian efek media massa terhadap khalayak bertujuan untuk mengetahui sejauhmana kehadiran suatu media atau proses penyampaian pesan mempengaruhi khalayak dalam berfikir, bersikap dan berperilaku. Penelitian efek ini juga digunakan untuk mengetahui sejauhmana perubahan sosial terjadi, karena kehadiran media atau karena pesan media massa.

\subsection{Televisi Publik pada UU Penyiaran No. 32 Tahun 2002}

TVRI sebagai TV Publik adalah status yang seharusnya dijalani oleh TVRI pada akhir tahun 2005, sebagaimana diamanatkan Undang-Undang Nomor 32 tahun 2002, tentang Penyiaran.

Menurut Subrata (2004) Undang-Undang Penyiaran No. 32 tahun 2002 menyebutkan bahwa lembaga penyiaran publik adalah lembaga penyiaran yang berbentuk badan hukum yang didirikan oleh negara. Badan hukumnya jelas persero bukan BHMN, bersifat independen, netral, tidak komersial dan berfungsi untuk memberikan pelayanan untuk kepentingan masyarakat.

Bagian keempat tentang lembaga penyiaran Pasal 14 dalam Undang-Undang Nomor 32 tahun 2002 menyebutkan: (1) lembaga penyiaran publik sebagaimana dimaksud dalam pasal 13 ayat (2) huruf a adalah penyiaran yang berbentuk badan hukum yang didirikan oleh negara, bersifat 
independen, netral, tidak komersial, dan berfungsi memberikan layanan untuk kepentingan masyarakat; (2) lembaga penyiaran publik sebagaimana dimaksud ayat (1) terdiri atas Radio Republik Indonesia dan Televisi Republik Indonesia yang stasiun pusatnya berada di ibu kota negara Republik Indonesia; (3) di daerah provinsi, kabupaten atau kota dapat didirikan lembaga penyiaran publik lokal; (4) Dewan Pengawas dan Dewan Direksi lembaga penyiaran publik dibentuk sesuai dengan peraturan perundang-undangan yang berlaku; (5) Dewan Pengawas ditetapkan oleh Presiden bagi Radio Republik Indonesia dan Televisi Republik Indonesia atas usul Dewan Perwakilan Republik Indonesia, atau oleh Gubernur, Bupati atau Walikota bagi lembaga penyiaran publik lokal atas usul Dewan rakyat Daerah, setelah melalui uji kepatutan dan kelayakan secara terbuka atas masukan dari pemerintah dan atau masyarakat, (6) Jumlah dewan Pengawas bagi Radio Republik Indonesia dan televisi Republik Indonesia sebanyak lima orang dan Dewan Pengawas bagi lembaga penyiaran publik sebanyak tiga orang. (7) Dewan Direksi diangkat dan ditetapkan oleh Dewan Pengawas, (8) Dewan Pengawas dan Dewan Direksi Lembaga penyiaran Publik mempunyai masa kerja lima tahun dan dapat dipilih kembali hanya untuk satu kali masa jabatan berikutnya, (9) Lembaga penyiaran publik di tingkat pusat perlu diawasi oleh Dewan Perwakilan Rakyat Republik Indonesia dan Lembaga Penyiaran Publik di tingkat Daerah oleh Dewan Perwakilan Rakyat Daerah, (10) Ketentuan lebih lanjut mengenai lembaga Penyiaran Publik disusun oleh Komisi Penyiaran Indonesia (KPI) bersama Pemerintah.

Menurut Mulyana (2004), dalam konteks TVRI menjadi TV Publik sebagai tv alternatif yang perlu program berbeda (lebih bermanfaat) dibanding dengan TV swasta yang secara implisit menunjukkan segmen khalayak yang berbeda pula, khususnya berbeda di pedesaan dan belum terjangkau oleh TV swasta dan di wilayah-wilayah yang belum menerima pancaran TV swasta secara jernih. Sebagai TV alternatif, TVRI sebagai TV Publik dapat melakukan pencerahan terhadap khalayak pemirsanya. Pendek kata, TVRI sebagai
TV Publik harus punya identitas dan pola acaranya tersendiri, tanpa harus bersaing dengan TV swasta yang sudah ada.

Lebih jauh Mulyana (2004) menyebutkan sejalan dengan kebijakan pemerintah yang kini menganut asas desentralisasi (otonomi daerah), kita perlu mengembangkan TV kita yang lebih membumi, yang mencerminkan keanekaragaman masyarakat Indonesia terutama dilihat dari ras, suku dan agama mereka. Solusinya adalah TV Publik.

Dalam penelitian yang berkenaan dengan Televisi sebagai media massa, dapat dilakukan sebagai berikut:

- Audience Research

- Audience Respons

Communication Impact

- Process of Influence

Penjelasan dari pengukuran efektivitas dari mass media/sarana komunikasi dapat dijelaskan antara lain sebagai berikut:

(1) Audience Research

a. Berapa banyakkah audience yang dapat dijangkau

b. Siapa saja mereka itu

c. Berapa banyak mereka itu dari audience yang diinginkan

(2) Audience Respons

a. Bagaimanakah anggota-anggota audience memberikan respons

b. Apakah isi pesan itu dapat dimengerti secara baik ataukah tidak dapat dimengerti

c. Apakah menimbulkan atau menumbuhkan perhatian mereka

d. Apakah menjemukan

e. Apakah mereka memahami

(3) Communication Impact

a. Apakah reaksi yang timbul

b. Apakah yang membekas pada audience

(4) Process of Influence

a. Apakah proses komunikasi yang mempengaruhi targetnya

b. Melalui saluran-saluran apakah mekanisme persuasi itu berlangsung

c. Bagaimanakah efektivitas program yang mengarahkan audience? 


\section{Objek dan Metode Penelitian}

\subsection{Objek penelitian}

Objek penelitian ini adalah masyarakat Kota Bandung. Respondennya adalah kepala keluarga yang menonton TVRI

\subsection{Metode Penelitian}

Penelitian ini bersifat deskriptif dengan pendekatan survei.

Teknik sampling yang digunakan adalah multi stage area sampling, dan diperoleh 250 (dua ratus lima puluh) kepala keluarga/umpi. Penentuannya adalah sebagai berikut:

Pada tahap satu, dari sebanyak 26 kecamatan di Kota Bandung dipilih secara acak tiga kecamatan, dalam hal ini adalah Kecamatan Sukasari, Cibeunying dan Batununggal. Kecamatan tersebut masing-masing memiliki empat, enam, dan delapan kelurahan. Tahap kedua, dari wilayah kecamatan yang terpilih tersebut dipilih secara acak satu kelurahan, yaitu Kelurahan Isola, Cikutra, dan Kebon Waru. Kelurahan tersebut masing-masing memiliki enam, lima belas, dan delapan rukun warga (RW). Pada tahap ketiga, dari kelurahan yang terpilih secara acak, selanjutnya masing-masing diambil secara acak satu RW dari Kelurahan Isola, dua RW dari Kelurahan Cikutra, dan satu RW dari Kelurahan Kebon Waru, dalam hal ini RW 04, RW 05 dan 02, dan RW 08. Banyaknya rukun tetangga (RT) di masing-masing RW adalah delapan, delapan, dan tujuh. Pada tahap keempat dipilih secara acak sejumlah RT, yaitu satu RT dari RW 04, dua RT dan RW 05 dan 02; dan satu RT dari RW 08, dalam hal ini adalah RT 06 terpilih secara acak 78 umpi, RT 02 sebanyak 55 umpi dan 05 sebanyak 57 umpi; dan RT 08 sebanyak 60 umpi. Jumlah umpi yang terpilih ditetapkan secara proposional sehingga banyak umpi secara keseluruhan adalah 250. Karena unit analisis merupakan umpi, maka jenis sampling ini hanya sampai lima tahap.

Tehnik pengumpulan data melalui kuesioner, studi pustaka dan juga dilengkapi dengan wawancara mendalam dengan tokoh atau mereka yang memiliki ketertarikan dengan media/televisi, baik praktisi maupun teoritisi atau anggota lembaga yang relevan dengan masalah pertelevisian.

Dalam penelitian variabel konseptual yang digunakan ialah sosio demografis responden yang meliputi jenis kelamin, usia, pendidikan, pekerjaan, penghasilan dan media komunikasi yang dipilih.

Sedangkan yang menjadi unsur-unsur yang mendapat opini dari respondennya adalah sosialisasi, penilaian, harapan dan kontribusi masyarakat terhadap/pada TV Publik.

\section{Hasil Penelitian dan Pembahasan}

\subsection{Identitas Responden}

Distribusi responden penelitian memperlihatkan bahwa terdapat $54 \%$ pria dan $46 \%$ wanita, sedangkan dari faktor usia, terdapat $32 \%$ yang berusia kurang dari 25 tahun, $45 \%$ berusia $25-35$ tahun, dan $23 \%$ lebih dari 35 tahun. Dari hasil tersebut hal yang menarik adalah bahwa pemirsa TVRI paling tinggi prosentasenya adalah yang berusia antara 25 - 35 tahun, karena usia ini merupakan usia yang oleh sementara kalangan diduga tidak suka menonton TVRI.

Selanjutnya dari aspek pendidikan, prosentase tertinggi yang menonton TVRI adalah dari SMU/ sederajat, yakni 49,20\%; yang berpendidikan SD, 2,80\%, SMP/sederajat 4,80\%, sarjana dan lainnya $43,20 \%$. Hal ini menunjukkan bahwa TVRI diminati oleh semua strata pendidikan dan ini merupakan "peluang" yang baik bagi TVRI dalam konteks menjadi TV Publik.

Responden penelitian ini dilihat dari segi pekerjaan ternyata menunjukkan bahwa yang paling banyak adalah pemirsa yang pekerjaannya adalah wiraswasta (42\%), baru PNS/TNI sebesar $28 \%$. Ini mengisyaratkan bahwa kelompok terbesar prosentasenya tersebut patut menjadi pertimbangan bagi TVRI dalam konteks menjadi TV Publik.

Dari aspek penghasilan, responden terbanyak adalah berpenghasilan kurang dari satu juta $(62,40 \%)$. Yang penghasilannya $1-1,5$ juta $22,40 \%$ sisanya 1,6 juta sampai 4 juta lebih.

\subsection{Dari Kuesioner}

Sebagaimana dikemukakan terdahulu bahwa 
penelitian ini dilakukan untuk "menjaring" informasi sebelum TV Publik direalisasikan. Informasiinformasi atau temuan-temuan yang diperoleh berkenaan dengan sosialisasi, pengetahuan (kognisi), penilaian, harapan dan kemungkinan kontribusi masyarakat dalam konteks terealisasinya TV Publik. Berikut hasil penelitian yang dimaksud.

(a) Sosialisasi melalui roadshow, sangat setuju dan setuju $=84,40 \%$ (walaupun belum gencar sosialisasinya).

(b) Publik lebih mendidik dan tidak komersil (aspek kognisi) à $68 \%$

(c) Setuju TVRI jadi TV Publik (75,20\%)

(d) Indonesia sudah sepatutnya punya TV Publik $(18,80 \%)$

(e) TV Publik untuk kepentingan masyarakat (90 $\%)$

(f) Evaluasi responden: pengemasan acara harus lebih menarik $30,80 \%$.

(g) Jam tayang untuk kepentingan publik perbesar $(87,60 \%)$

(h) Acara-acara TV Publik harus berorientasi pada budaya masyarakat dan dapat mencerdaskan bangsa $(91,20 \%)$

(i) TV Publik bukan TV Pemerintah dan tidak tunduk pada hukum pasar $60,80 \%$

(j) TV Publik harus bertujuan meningkatkan kualitas bangsa $(89,60 \%)$

(k) Sebagian responden setuju publik ikut iuran (kontribusi materi).

Dari prosentase pendapat responden melalui kuesioner tersebut dapat dijelaskan sebagai berikut:

Sosialisasi TV Publik melalui Road Show belum begitu gencar, dan masih bisa ditingkatkan. Melihat data ini tentunya perlu optimalisasi sosialisasi. Perlu dikaji lagi metoda Road Show seperti apa, sehingga kegiatannya lebih murah lagi dan menjadi perhatian masyarakat. Selain itu juga perlu dikaji lagi, misalnya Road Show dalam bentuk special event, yang lebih kelihatan dan publik tertarik, dan dapat menggugah keingintahuan sehingga akan cukup lama mereka ingat.

Masalah sosialisasi melalui media massa juga belum memadai; responden menilai hanya sampai tingkat rata-rata. Jadi masih punya waktu lagi bagi TVRI untuk lebih mensosialisasikannya.

Media massa cetak dan elektronik sebagai pembentuk opini publik, nampaknya perlu dioptimalkan dalam kegiatan sosialisasi ini; yang penting dipilih media yang ada dengan segmen yang jelas, sehingga tepat sasaran.

Pengetahuan mereka tentang TV Publik melihat asas legalitas dalam bentuk UU Penyiaran No. 3 tahun 2002, masih belum tinggi; sekira $25 \%$ masih belum mengetahuinya. Suatu prosentase yang cukup besar dilihat dari kekurang pengetahuan tersebut.

Harapan masyarakat, dalam hal ini, menginginkan TVRI lebih banyak/meningkatkan porsi tayangan untuk kepentingan publik diperbesar; jangan "terjebak" dengan acara-acara yang aspek komersialnya lebih dominan.

Penilaian responden tentang komposisi kelompok mata acara program yang terdiri dari agama (20,4 \%), Talkshow (8,29\%), Drama (18,81 $\%$ ), Musik (9,9\%), Hiburan (19,49\%), Dokumenter (3,34\%), Kuis (15,43\%), Film Kartun (3,43\%), Film $(9,07 \%)$ terdapat pada peringkat rata-rata. Nampaknya masih perlu dipertimbangkan agar acara-acaranya lebih berorientasi kepada kepentingan publik yang berlatar pendidikan dan budaya

Sebagian responden setuju bahwa sebagai lembaga penyiaran (TV Publik), TVRI berbentuk badan hukum yang didirikan negara, bersifat independen, sosial, tidak komersial dan berfungsi memberikan pelayanan untuk kepentingan masyarakat. Yang penting bahwa independensi TV Publik sangat diharapkan. Kendati selain adanya iuran Publik dan subsidi dari pemerintah untuk biaya operasional TV Publik, bukan berarti pemerintah bisa intervensi pada tayangan TV Publik.

Sejumlah 67,20\% responden setuju sumber pembiayaan TV Publik terdiri dari iuran penyiaran masyarakat. APBN/APBD, sumbangan masyarakat (donatur) dan sebagainya. Yang menarik di sini ternyata sebagian responden (masyarakat) bersedia memberikan kontribusinya kepada TV Publik. 


\subsection{Dari Hasil Wawancara}

Untuk melengkapi kajian ini, dilakukan wawancara dengan beberapa tokoh dan pakar yang memiliki relevansi dengan tema penelitian ini, yakni DR.Sasa Djuarsa, Drs. Suhardi, M.Si., Drs. H.A.M. Ruslan, Drs. Yoyo S.Adiredja, Drs.France Djasman dan Karni Ilyas, S.H. Berikut hasil wawancara tersebut:

(a) Pada prinsipnya kehadiran TV Publik merupakan hal yang positif bagi perkembangan pertelevisian di tanah air walaupun banyak kendala yang mungkin muncul.

(b) Menurut kalangan dari TV Swasta masyarakat tidak akan terlalu menuntut program-program kepada televisi swasta.

(c) Badan hukum TV Publik harus independen dan biayanya dari negara, bukan pemerintah.

(d) Program idealnya harus bertitik berat pada pendidikan dan budaya nasional maupun lokal.

(e) TV Publik harus lebih utama dalam menjaga integritas bangsa dan kebudayaan, dalam arti mempertahankan dan mengembangkan identitas budaya bangsa.

(f) Sikap mental dan kinerja dari SDM pada TVRI sebagai TV Publik harus berubah, sebab harus "bersaing" dengan TV swasta. Paling tidak kualifikasi SDMnya adalah: memiliki profesionalisme, berwawasan luas, sense of journalismnya tinggi, mempunyai kreativitas dan daya inovasi yang tinggi serta memiliki semangat belajar sepanjang hayat.

(g) TV Publik harus melayani masyarakat dalam arti yang sesungguhnya.

(h) TV Publik harus tetap mempertimbangkan trend pasar, tetapi tidak menjadi "mainan" pasar.

(i) TV Publik bukan corong pemerintah tetapi corong negara; oleh karena itu loyalitas TV Publik harus pada kepentingan masyarakat.

(j) Perlu diingat, kekuatan TV Publik adalah pada manajemen yang baik dan benar.

(k) Adanya TV publik merupakan "kemenangan" daerah. Melalui saluran daerah justru budaya daerah dapat berkembang lebih optimal.

(l) Masalah lain pada TV Publik adalah dana. (m) Ada kesulitan yang harus diperhatikan kalau hendak memiliki TV Publik yang sesungguhnya.

Dari berbagai butir hasil wawancara tersebut di atas dapat dikemukakan bahwa untuk menjadi TV Publik yang sesungguhnya, bukan hal yang mudah, sebab banyak faktor dan kendala-kendala untuk menciptakan atau merealisasikan TV Publik yang "memenuhi persyaratan" sebagai TV Publik yang sebenarnya. Hal ini diakibatkan oleh berbagai kendala yang dihadapi dalam merealisasikan sebuah TV Publik sebagai perspektifbaru di negara kita.

\section{Kesimpulan dan Rekomendasi}

\subsection{Kesimpulan}

(a) Upaya ke arah terealisasinya TV Publik masih dinilai masyarakat belum cukup, terutama dari segi mensosialisasikannya. Konsekuensinya pengetahuan masyarakat tentang TV Publik masih kurang. Masyarakat mengharapkan TV Publik lebih bernuansa mendidik karena mereka berpendapat bahwa sudah saatnya masyarakat disuguhi program-program yang sesuai dengan fungsi TV Publik. Mereka berharap agar kehadiran TV Publik dapat membuat pikiran lebih jernih dan membawa masyarakat lebih "matang”. Yang juga menarik dari hasil penelitian ini ialah bahwa sebagian responden bersedia membantu atau memberikan kontribusi berupa iuran. Mereka juga setuju ada iklan tetapi yang sehat.

(b) Dari beberapa pakar dan tokoh baik media elektronik maupun media cetak, dapat disimpulkan bahwa kehadiran TV Publik merupakan hal yang positif, walaupun berbagai kendala dan tantangan akan dihadapi.

\subsection{Rekomendasi}

Dari hasil penelitian, pembahasan dan kesimpulan, direkomendasikan sebagai berikut:

(a) Sosialisasi yang berkaitan dengan TV Publik masih perlu ditingkatkan, sehingga masyarakat lebih memahami. 
(b) Perlu ditingkatkannya program-program, pada TV Publik, yang bersifat mendidik dan mempertahankan budaya bangsa.

(c) Peningkatan kualitas SDM sangat diperlukan.

(d) Manajemen yang baik perlu menjadi perhatian utama dari pengelolaan TV Publik, sebab merupakan dasar pencapaian fungsi dari TV Publik.

(e) "Peluang" harapan dari masyarakat agar TV Publik lebih menitikberatkan pada fungsi mendidik, dan mengembangkan budaya bangsa, agar "disiasati” dalam pengemasan program-program Televisi Publik.

(f) Diperlukan penelitian lanjutan dari berbagai aspek tentang TV Publik setelah direalisasikan.

\section{Daftar Pustaka}

Adam, Raider, Legowo, T.A. dan Jonathans, Erol. 2000. Politik dan Radio. Jakarta: FriedrichNaumann-Stiftung.

Aziz, M. Abduh. 2001. "Pokok-Pokok Pikiran Mengenai Pengembangan Program TV Publik" (Makalah), dalam Semiloka Sosialisasi TV dan Radio Publik di Bandung. 26-27 Juli.

Azwar Saifuddin. 1995. Sikap Manusia, Teori dan Pengukurannya. Yogyakarta: Pustaka Pelajar.

Biagie, Shirley. 1996. Media/Impact: An Introduction to Mass Media. Belmont, California: Wadsworth Publishing Company.

Brugger, David. 2001. "Menciptakan ruang bebas melalui Dauya Jangkau" (Makalah). Dalam Semiloka Sosialisasi TV dan Radio Publik di Bandung, 26-27 Juli.

Croteau, David and william Hoynes. 1997. Media Society: Industries images, and audiences, London: Pine Forge Press.
Cutlip, Scot M. 2005. Effective Public Relations. (Merancang dan melaksanakan Humas yang sukses). Jakarta.

Dominick, Joseph R. 1987. The Dynamics of Mass Communication. New York: Random House.

Gazali, Effendi. 2001. Pengantar Semiloka. Sosialisasi TV \& RadioPublik"(Makalah), dalam Semiloka Sosialisasi TV dan Radio Publik di Bandung, 26-27 Juli 2001.

Grossberg, Lawrence, Elen Wartella, D. Charles Whitney. 1998. Media Making: Mass Media In A Popular Culture. California: Sage Publications. Inc.

Hidayat, Dedy. N. 2001. "Radio Televisi Akses Publik dan Rekomendasi" (Makalah), dalam Semiloka Sosialisasi TV dan Radio Publik di Bandung, 26-27 Juli.

Idris, Soewardi. 1987. Jurnalistik Televisi. Bandung: Remaja Karya.

Joseph, LaRose, Robert. 1997. Communications Media in the Information Society. Belmont, California: Wadsworth Publishing.

Malik, Dedy Djamaluddin. 2001. "Posisi dan Peran TV Publik" (Makalah), dalam Semiloka Sosialisasi TV dan Radio Publik di Bandung, 26-27 Juli.

Mencher, Melvin. 1997. News Reporting and Writing. Madison, WI Dubuque: Brown \& Benchmark.

1986. Basic News Writing. Dubuque, Iowaq: Wm. C. Brown Publishers.

Muda, Deddy Iskandar. 2003. Jurnalistik Televisi. Bandung: Remaja Rosdakarya.

Potter. W. James. 1998. Media Literacy. California: Sage Publications. Inc.

Widjanarko. 2001. "Publik dan Lembaga Penyiaran Publik" (Makalah), dalam Semiloka Sosialisasi TV dan Radio Public di Bandung, 26-27 Juli. 